\title{
18
}

\section{PATHWAYS OF DUTCH AND GERMAN SOCIAL RENTING}

\author{
Marietta E.A. Haffner
}

\section{Introduction}

After the Second World War, the private rental sector dominated the housing stock of the Northwestern European countries (Haffner et al., 2008, 2009). In the post-war period, the market share of private renting declined because of multiple reasons. On the one hand, the shares of owner-occupation and/or social rental units increased, while on the other hand, regulation of rents and security of tenure characterized the private rental sector, sometimes up until the 1980s (Hoekstra et al., 2012; Haffner et al., 2018). As an exponent of this development, the Netherlands reached one of the lowest market shares of private renting (9\% in 2012). Germany will be the atypical case, where private renting amounts to more than $40 \%$ or even $50 \%$ of stock, depending on the definition (2011), one of the highest market shares (Haffner, 2018a, 2018b). In both countries, in recent decades the share of affordable (Dutch social and German subsidized) rental stock has lost ground. Both countries have been coping with affordability problems in the rental sector in this century (Elsinga and Haffner, 2020).

The contribution aims to develop an understanding of the pathways of Dutch and German housing policies resulting in two different housing markets and housing systems, while coping with affordability problems in the rental sector since the early 2000s. These affordability problems are briefly sketched in the next section. Thereafter, the term 'social' in the sense of affordable rental housing is framed in each country's context with a focus on their supply-side history till 2017. Finally, the chapter reviews the impact of these developments on the expected role of 'social' renting as rental housing with affordable costs.

\section{Affordability Outcomes in Germany and the Netherlands}

Germany and the Netherlands can be considered opposite cases in the market share of private/commercial/market renting. However, the rental sector in the Netherlands (over 30\%) amounts to about the average share of the 28 member countries of the European Union (EU), measured as share of population. The German (private) rental sector is the largest, even though not all EU member states are shown. Data refer to 11 member countries of the 28 in the EU, those considered comparable with Western advanced economies (Figure 18.1). Both countries are more similar than different when comparing the shares of the at-risk-of-poverty population, those with an equivalized 


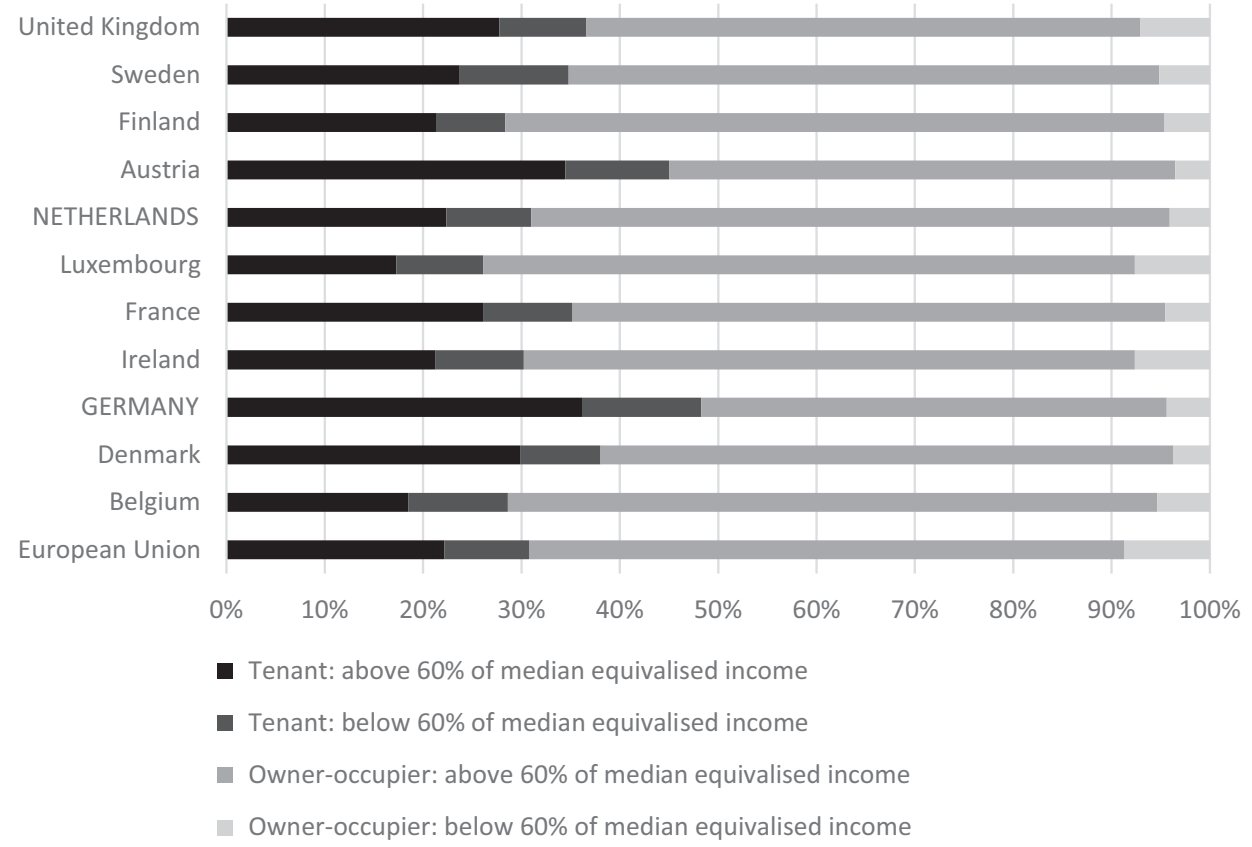

FIGURE 18.1 Tenure Structure Percentage of Population by Income Group ${ }^{1,2}, 2016$.

1 As classified according to share of population with an equivalized disposable income lower or higher than $60 \%$ of the median national equivalized income after social transfers. Equivalized indicates that income is corrected for household composition (Eurostat, n.d.-a).

2 Data refer to 11 member countries of the 28 in the European Union.

Source: Eurostat (n.d.-b) (EU-SILC 2016 data base): calculation based on groups of ilc_li02 and ilc_lvho02.

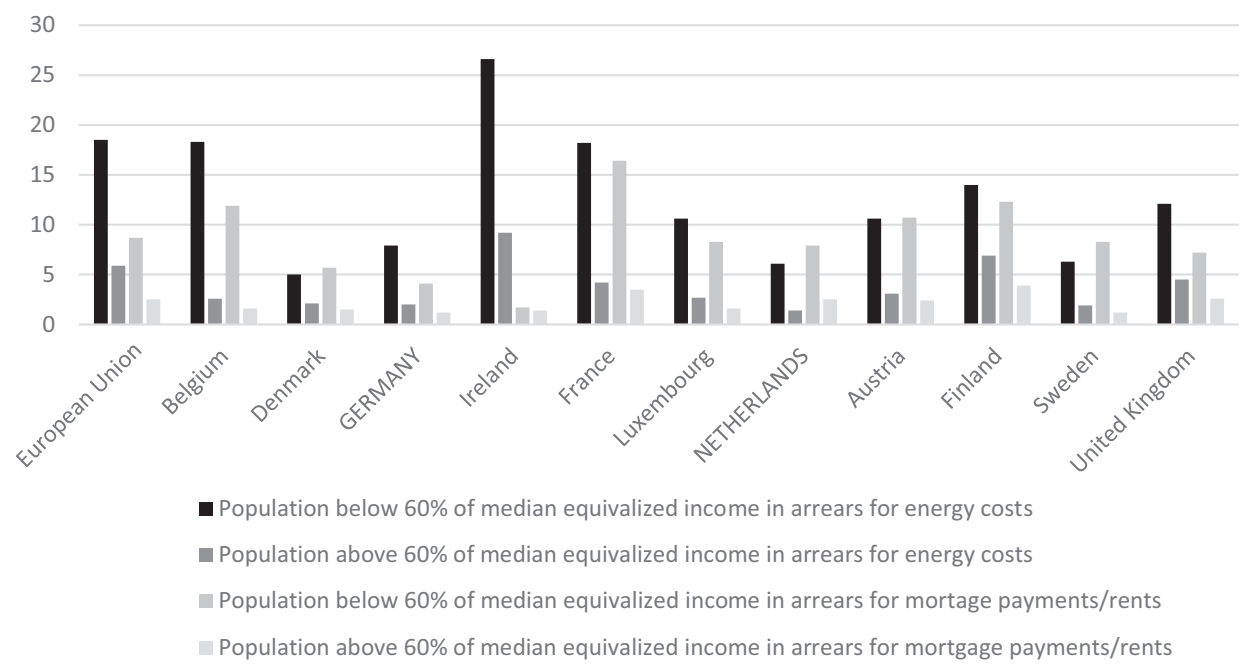

FIGURE 18.2 Share of Population with Arrears on Mortgage Payments/Rents or Utility Bills ${ }^{1}$ by Income Group ${ }^{2}, 2016$.

1 Eurostat (n.d.-a): "These arrears take into account the amount owed (bills, rent, credit/mortgage repayment...) which is not paid on schedule during the last 12 months for financial reasons".

2 For definition of income group, see note 1, Figure 18.1. Data refer to 11 member countries of the 28 in the European Union.

Source: Eurostat (n.d.-b) EU-SILC 2016 data base: ilc_mdes06 and ilc_mdes07. 

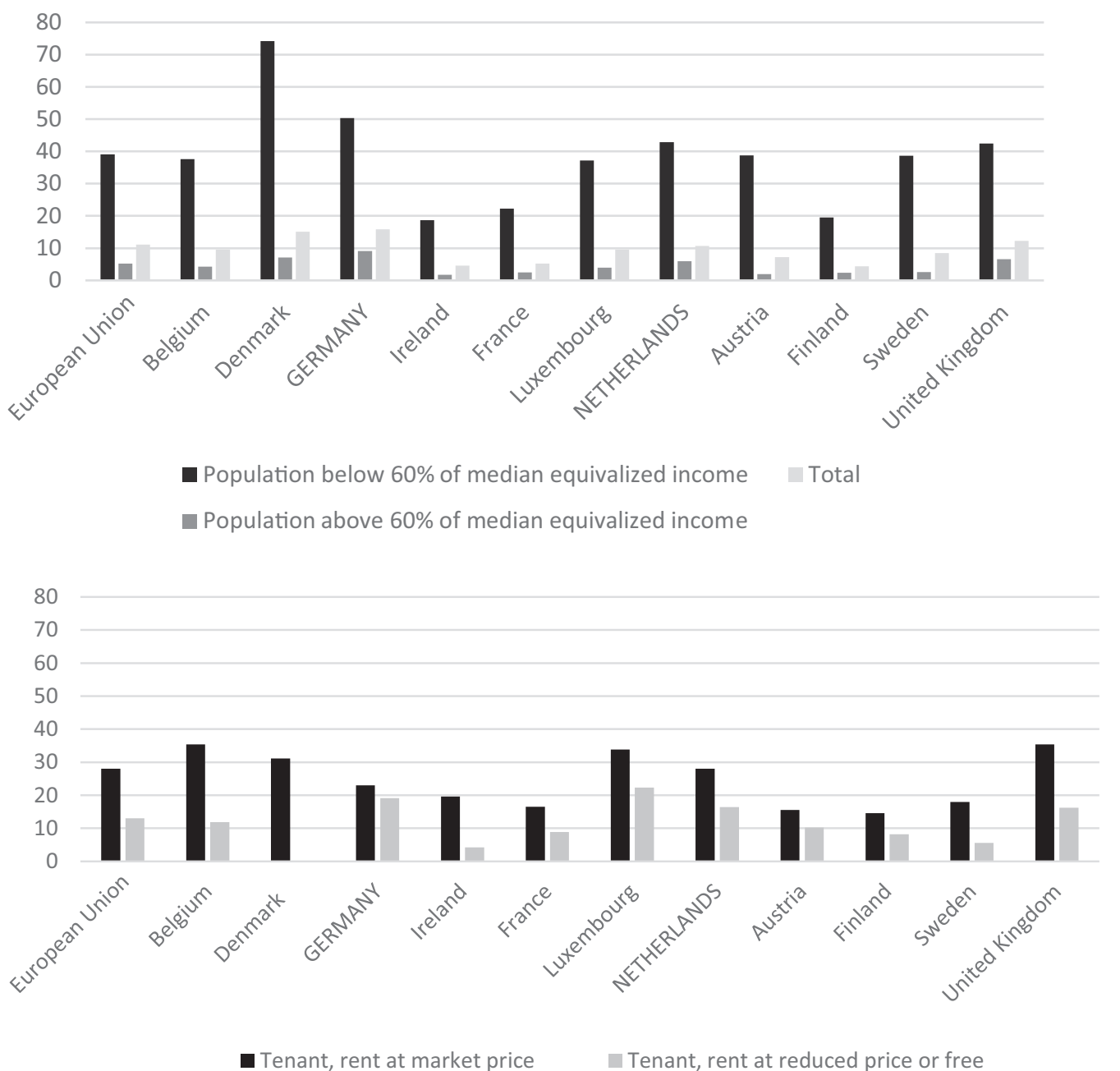

FIGURE 18.3 Housing Cost Overburden Rate ${ }^{1}, 2016$ : (a) by income group ${ }^{2}$ (b) by rental status ${ }^{3,4}$.

1 Share of population living in households where the total housing costs ('net' of housing allowances) represent more than $40 \%$ of disposable income ('net' of housing allowances) (Eurostat, n.d.-a).

2 For definition of income group, see note 1, Figure 18.1.

3 Tenant rent at market price includes tenants for which the distinction between both categories of renting is unclear (Eurostat, 2017).

4 Low reliability for share of tenants with rent at reduced price or free. Data refer to 11 member countries of the 28 in the European Union.

Source: Eurostat (n.d.-b) EU-SILC 2016 data base: ilc_lvho07a and ilc_lvho07c.

disposable income below $60 \%$ of median equivalized income. Together with Austria and Denmark, both countries house the lowest shares of such populations in owner-occupied dwellings.

In the fight against poverty and social exclusion, the 28 member states of the EU have been drawing up National Action Plans for Social Inclusion since the Lisbon European Council (European Council, 2000). To monitor progress, the EU set up the EU Statistics of Income and Living Conditions database providing a variety of measures on housing affordability (EUSILC; European Commission, 2009). Data on subjective measures, such as resident's perceptions of housing costs as a (heavy) financial burden, indicate that $70 \%$ of the EU-population is in this category. Using two 'objective' measures as indicators of housing affordability, the 
two countries perform in a similar way (Eurostat, n.d.-b). With their population in arrears on mortgage/rent payments or on utility bills in the groups below (low income) and above 60\% of median equivalized income, Germany and the Netherlands both score below EU-average (Figure 18.2). The shares of their population in arrears are lower or equal. However, in Germany, the lower-income population is more likely to be in arrears when paying energy costs, while in the Netherlands, it is more likely to be in arrears when paying rents.

Figure 18.3 shows the so-called housing cost 'overburden' rate by income group and by rental tenure. It is expressed as share of population living in households where the total housing costs ('net' of housing allowances) represent more than $40 \%$ of disposable income ('net' of housing allowances). The costs include energy costs, among others, as well as maintenance costs and rents. The population at risk of poverty is more likely to be housing cost overburdened (Figure 18.3a), as well as the tenants paying market rent (Figure 18.3b).

In relation to the latter group, tenants paying market rent, when housing affordability is at stake, the distinction between reduced rent/free is not clear. Eurostat (2017: 169) explains: "In a situation where there is no clear distinction between a 'prevailing rent' rent sector and a 'reduced rent' sector, all renters would be classified as 'tenant or subtenant paying rent at prevailing or market rate'." This applies to the Netherlands, where most of the existing social rental housing is classified as market rent in this figure, while only 0.7 percentage of the total $31 \%$ of the tenant population is classified as paying reduced rent. The shares for Germany are more in line with those given in the literature. The tenant population amounts to $48.6 \%$, while $8.4 \%$ is classified as tenants paying reduced rent in 2016.

As last indicator of affordability, Figure 18.4 shows the impact of housing costs on the atrisk-of-poverty rate. Housing costs clearly more than double the share of the population considered to live at risk of poverty in the Scandinavian countries, the United Kingdom, as well as Germany and the Netherlands, more so than the average in the 28 EU-countries. Therefore, housing costs on average push a larger share of population into living at risk of poverty.

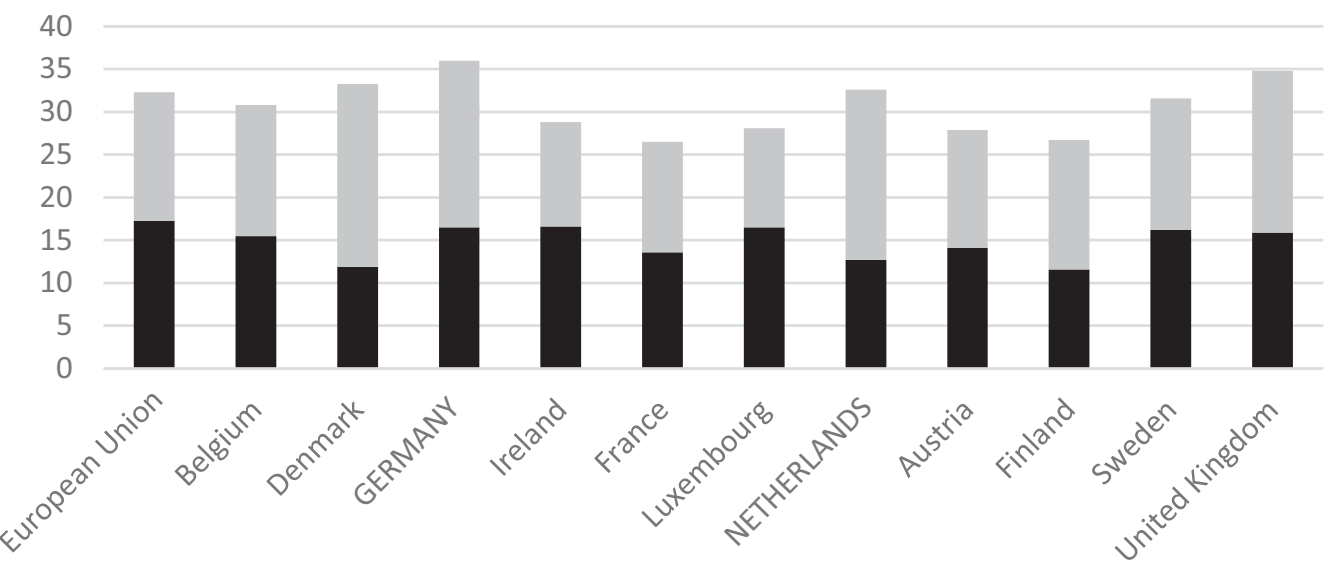

- At risk of poverty rate $\square$ Increase of rate after deducting housing costs

FIGURE 18.4 After-Housing Costs at-Risk-of-Poverty ${ }^{1}$ Rate Increase ${ }^{2}, 2016$.

1 Population at risk of poverty is defined as population with an equivalized disposable income below $60 \%$ of median equivalized income in a country (Eurostat, n.d.-a).

2 Increase of rate after deduction of housing costs from income, calculated per group rather than per person. Data refer to 11 member countries of the 28 in the European Union.

Source: Eurostat (n.d.-b) EU-SILC 2016 data base: calculation based on groups of ilc_li45 and ilc_li02. 
In conclusion, this section shows the outcomes for different types of affordability indicators all being based on some relation between housing costs and income, which would be considered a usual definition of affordability (Haffner, 2018b). The indicators show an impact resulting in tenants being deemed to live at risk of poverty, being overburdened with housing costs or being in housing arrears. The latter two come with a standard definion of housing costs being deemed 'too high', and therefore being unaffordable. While a discussion about standards of unaffordability is possible, arrears definitely expose an affordabilty problem. On arrears, Germany and the Netherlands score better than the EU-average, while on both of the other indicators, they score worse. As 'reduced-rent', often called social rent, is associated with housing being more affordable based on a public task definition and supply-side subsidies, the remainder of the chapter focuses on its development and impact in the two countries under review.

\section{Origins of 'Social' Rental Housing in Both Countries}

Even if affordability outcomes are similar today, Germany and the Netherlands made different choices after the Second World War (Boelhouwer and Van der Heijden, 1992; Haffner et al., 2009; Whitehead et al., 2016; Elsinga and Haffner, 2020). The Netherlands made the more usual choice in Western countries at that time entailing the designation of certain non-profit housing associations (and local authorities) for operating a social rental sector. More unusual was the choice to put these organizations at arm's length and designate them as non-profit rather than public.

Germany did not set about to create a social rental sector linked to the ownership of the dwelling. Germany designed a supply-side subsidy system with the aim to temporarily subsidize any interested investor (public, private, commercial or non-profit) for providing subsidized housing limited to the subsidy period. Therefore, Germany does not operatie a formal social (rental) sector, but a private rental sector, next to (private) homeownership. Within these private markets, the country follows its social aims by temporarily subsidizing dwellings which are to be offered to the policy target group. Subsidized dwellings would be realized with lower-thanmarket price, depending on relationship between building costs and market price in a location.

In both countries, 'market', private or no longer subsidized rental dwellings, however, operate with the support by rent allowance (demand support) and rent price regulation. Private renting, as well as 'social' renting, is regulated in terms of 'indefinite' tenant security. This would entail indefinite rental contracts linked to a limited number of eviction reasons identified in the relevant legal framework (Haffner et al., 2008, 2009).

\section{Germany}

Important for the housing policy design in West Germany was the social market economy philosophy (Boelhouwer and Van der Heijden, 1992; Haffner et al., 2009; Elsinga and Haffner, 2020). After the Second World War, Germany put into practice that social welfare is best served by bringing about economic progress, while government intervention is designed to support the market (Busch-Geertsema, 2000, 2004). Implementation entailed (1) temporary government intervention in the market and (2) tenure neutral housing policy design in order to prevent favourable treatment of one tenure above another. Housing allowances are available, irrespective of the status of the occupier, being tenant or owner (Elsinga and Haffner, 2020). Bricksand-mortar or supply-side subsidies for housing also fulfilled the criterion of tenure neutrality (Leutner, 1990; Haffner et al., 2009; Oxley et al., 2010). Furthermore, they were also designed as temporary support with a limitation of the subsidy period. The period lasted up to five 
decades in the early days of subsidization, while it was reduced to ten to 15 years more recently (Cornelius and Rzeznik, 2014; Kofner, 2017).

The Housing Law of 2001 overhauled the law of 1956, but kept the supply-side subsidy mechanisms intact (Busch-Geertsema, 2000; Bundesministerium für Verkehr, Bau- und Wohnungswesen 2001; Haffner et al., 2009; Haffner, 2011; Oxley et al., 2015; Elsinga and Haffner, 2020). In the case of rental housing, the investor in rental housing could receive either a low-cost loan or an interest subsidy and agreed in exchange to limitation of initial rent levels and on rent increases in combination with dwelling allocation rules to facilitate access for the policy target group. Such system of bricks-and-mortar subsidies operates as a concession model. It ring-fences temporarily subsidized dwellings from the rest of the housing market under a special regime. Once the subsidy period ends, the dwelling becomes an unsubsidized rental dwelling.

The Housing Law of 2001 also brought some changes. First, the subsidy started targeting lowincome and other vulnerable groups rather than the population more broadly; second, it shifted towards buying rights of access to existing private rental stock (strengthening neighbourhoods) rather than being applicable to newly built stock only (Bundesregierung, 2006; Brech, 2014; Kofner, 2017). The supply-side subsidy system required all levels of government in the German federal country to cooperate: the national/federal government, the governments of the 16 federal states and the local governments (Haffner et al., 2009). The local governments negotiate subsidized housing with the local potential investors. In the past, the national government formulated the legal framework for the system (Bundesregierung, 2009; Haffner, 2011; Elsinga and Haffner, 2020).

This changed in 2006 when the national government transferred its powers for subsidization, including the regulation of prices/rents and allocation, to the 16 federal state governments. This transfer was to allow federal states to design their own 'social' housing investment policies within urban and spatial policies in response to differentiated population development. The shift in responsibility from national government to federal state governments was accompanied by a financial compensation paid annually by the federal government until the end of 2013, which was later extended until to the end of 2019 (Bundesregierung, 2009; Oxley et al., 2010, 2015; Haffner, 2011; Bundesgesetzblatt, 2013; Kholodilin, 2017; Kofner 2017; Elsinga and Haffner, 2020).

Potential investors in subsidized rental housing used to be commercial investors/developers/landlords. More recently, the so-called housing companies became dominant as a seven-city case study by Bundesinstitut für Bau-, Stadt- und Raumforschung indicates (2012: 4). The shares of the housing companies are in the hands of local authorities, so this shift explains the lack of interest from other investors due to the low returns from subsidized rental dwellings (Oxley et al., 2010, 2015). The outcome is related to the fact that (personal and corporate) income tax depreciation deductions that compensate for lower negotiated returns from renting have become less attractive than they were in the past. Furthermore, Kofner (2017) observes that in the past, most subsidized projects were large-scale, located outside of city centres. The smaller and scattered projects of this century do not allow for such economies of scale and the advantages associated with it. The system of supply-side subsidies is designed as a concession model and the dwellings become part of the unsubsidized rental sector when the subsidy period terminates. As the subsidy periods have shortened in time, as well as the funds provided have decreased, the supply of subsidized rental housing has fallen. Cornelius and Rzeznik (2014) estimate the share of 'social'/subsidized rental stock at 4\% in 2011, and Kofner (2017: 62) at 3.3\% (see also Bundesamt für Bauwesen und Raumordnung, 2007; Kofner, 2014).

\section{The Netherlands}

In contrast to the developments in Germany, the Netherlands had established a social rental sector with the 1901 Housing Act. It enabled social landlords to become active: housing associations 
are registered (licenced, accredited) private non-profit housing providers or organizations (Boelhouwer and Van der Heijden, 1992; Haffner, 2002; Elsinga et al., 2005, 2008; Elsinga and Haffner, 2020). They were to obtain supply-side subsides from the national government, particularly after the Second World War. The choice for non-profit organizations rather than public organizations fitted well with the liberal spirit at that time (Van der Schaar, 1986).

After the Second World War, the reduction of the enormous housing shortage dominated the housing policies (Van der Schaar, 1987; see also Elsinga and Haffner, 2020). Among other measures, supply-side subsidies were introduced to increase rental housing production. The subsidy system was designed as annual revenue or management subsidies, which the national government paid for 50 years to the social landlord from the moment a dwelling was constructed. This subsidy closed the financial gap between rent level and norms for costs, both set by the government. As the national government determined the locations of newly built stock and the eligibility conditions, housing associations in fact turned into implementation organizations rather than independently operating entrepreneurs.

In the decades that followed, housing remained a subsidized service in the social rental sector. Homeowners also benefit from tax breaks (Boelhouwer and Van der Heijden, 1992; Haffner, 2002; Elsinga et al., 2005; Elsinga and Haffner, 2020). Tenure neutrality was implemented in the rental sector, where the same policies applied to private and social landlords with respect to rent setting, rent adjustment, indefinite rent contract and the number of eviction reasons (Haffner, 2018a). Furthermore, the supply-side subsides that were available for the housing associations were also available to private landlords. As the take-up required some administrative capacity, only private organization landlords/investors (insurance companies and pension funds) took advantage of them. Although financial support for social rental housing changed over the years, the supply-side subsidy regime remained intact for decades. The social rental stock increased from 12\% in 1947 to its highest market share of around $40 \%$ in the late 1980s, contributing to affordable stock for lower- as well as middle- and higher-income households.

The model that had been in place since the Second World War came to an end by the mid1990 s due to privatization notions permeating government policies. The subsidy obligations for 50 years for each newly built rental dwelling conflicted with EU financial requirements concerning national government budgets in preparation for the introduction of the common currency (Elsinga et al., 2005; Haffner et al., 2009, 2014; Elsinga and Haffner, 2020). Therefore, in the 1990s, all future subsidy obligations were paid in lump sum to the social and private landlords. This was called 'grossing and balancing', as the national government traded in its outstanding government loans that it had provided to the landlords to finance their investments in social rental housing. This operation cut the financing and subsidy link between the government and the social/private landlords. Social landlords were to operate as social entrepreneurs, acting in a commercial way, without supply-side subsidies for new construction, but fulfilling their public task of providing affordable housing for those in need. Financially, they were to operate as a revolving fund, earning revenues and using those revenues for improving the quality and quantity of their stock (Elsinga et al., 2005; Elsinga and Lind, 2013; Haffner et al., 2009, 2014; Elsinga and Haffner, 2020).

To facilitate and safeguard financial independence, two organizations were created. The Central Public Housing Fund, as safety net, was to step in when housing associations risked bankruptcy. Second, the Guarantee Fund for Social Housing Construction backed by government was to provide a guarantee to banks for loans taken out by housing associations; therefore, this constituted a new subsidy instrument. Furthermore, local authorities often lowered the price of land for the new construction of social rental housing. 
After a period of 'experimentation' with the new system, in which the local authority and social landlord worked together to realize social rental housing, the conservative-liberal national government set the aim to balance the housing market. This entailed a move towards market activities and away from social renting. The aim was to stimulate more private-commercial rental supply to help solve shortages in rental housing in the medium-price segment in the urban markets (Elsinga et al., 2008; Haffner et al., 2009, 2014). Different measures followed, such as an income limit for the allocation of social rental dwellings, which was introduced in 2011; it entailed explicit targeting to lower-income groups for the first time (Elsinga et al., 2005; Elsinga and Lind, 2013; Elsinga and Haffner, 2020). Meanwhile, these income limits have been lowered in the allocation of social rental dwellings to improve the fit between income and rent level (Haffner et al., 2014; Priemus and Haffner, 2017; Haffner, 2018a). Furthermore, social landlords no longer retained their exemption for corporate income tax, while a new 'property' tax was introduced in 2013 for dwellings with a low rent level. Particularly, the latter levy lowers social landlords' investment capacity. Another measure was making rent price regulation for social landlords stricter than for private landlords (Haffner, 2018a).

These measures contributed to the slow but steady decline of the share of the social rental sector reaching 30\% in 2015, down from 42\% in 1985 (Ministerie van Binnenlandse Zaken en Koninkrijksrelaties, 2016), while the private rental sector continued its decrease to $8 \%$ of dwelling stock in 2009 (Haffner, 2018a). These market share losses were compensated by the growth of homeownership starting from around $40 \%$ of stock at the end of the 1970s (Van der Heijden et al., 2002; Haffner et al., 2014).

\section{Impact on Affordability of Rental Housing}

The description of the models of affordable rental housing in Germany and the Netherlands, with their focus on supply-side subsidizaton, shows that different policies and tools have been implemented. However, both countries are coping with similar trends: decrease in subsidization, (relative) decrease in affordable rental housing and its targeting to lower-income households resulting in increasing maginalization of the subsidized/social rental sector (Bundesregierung, 2009; Oxley et al., 2015; Kholodilin, 2017, Kofner, 2017; Elsinga and Haffner, 2020; Hochstenbach and Ronald, 2020).

The Netherlands is facilitating such developments with its policies of giving more room to market actors. Measures such as limiting rent control increasingly to the cheaper rental stock and setting a lower-income limit in the social rental housing allocation system help to restrict the role of social renting, while the measures potentially open up opportunities for investment in the middle- and higher-priced segment of the private rental market (Oxley et al., 2015; Haffner, 2018a). Municipalities in unaffordable urban areas may aim to counteract such national measures (Hochstenbach and Ronald, 2020). Extra supply of private renting may increase much less slowly than expected, thereby further limiting options for social tenants to move on. Potential newcomers are thus waiting longer for the allocation of a social rental dwelling (Kromhout and Wittkämper, 2019).

Germany has lost subsidized stock, because of the conversion of subsidized rental housing into unsubsidized rental units after the end of the subsidy term of the respective dwelling(s). This causes households with a low income to be housed in the private rental sector with some form of demand-based subsidy and rent regulation to soften the move in the shorter term (Haffner et al., 2008; Haffner, 2011; Haffner et al., 2018). The loss of stock also causes Germany to have one of the smallest shares of subsidized/ 'social' rental housing on offer in the EU (Haffner et al., 2009; Oxley et al., 2010, 2015; Whitehead et al., 2016), as the stable rent levels did not require much 
new subsidized supply. For example, Berlin had stopped providing subsidies to 'social' housing in 2010 (Kofner, 2014).

Similar to Amsterdam, German cities have been discovering that the market share of subsidized rental housing may be too small to cope with the more recent growth of rent levels in a number of cities, signalling an increase in demand (Cornelius and Rzeznik, 2014; Kofner, 2017). Cities reacted by developing their own models of affordable housing provision. For example, Munich has developed a model of affordable housing, which is not aimed at the most needy, but is affordable to lower- to middle-income households. Other cities followed the lead (Cornelius and Rzeznik, 2014). In such models, planning gains need to be partially used for realizing affordable housing, similarly to the British Section 106 model. A big diversity in uses and schemes exist, while evaluations about effectiveness and efficiency are scarce (Cornelius and Rzeznik, 2014; Kofner, 2014). In both countries, the role of cities has increased and a variety of models and startegies has evolved to provide affordable housing to lower- to middle-income groups in growing metropolitan areas (Kholodilin, 2017; Hochstenbach and Ronald, 2020).

\section{Conclusions}

The country descriptions highlight how the supply-side subsidy models of affordable rental housing provision in Germany and the Netherlands have been implemented. The evolution since the Second World War has not changed their core characteristics and mechanisms for a large part of the 20th century. They can be described as path-dependent systems with mostly incremental changes, particularly the German system, which was/is steered by the market in combination with the societal/politically identified social needs and funding. The Dutch system has survived for a long time due to political agreement in Dutch society, which subsidized most housing from a paternalistic point of view. In the new century, the agreement has disappeared. The supply-side subsidy models of affordable rental housing provision in the Netherlands and in Germany were and still remain different in an important way. The Dutch model entails ownership of social rental housing by non-profit housing associations, creating a more permanent social rental stock. In contrast, the German system produces a temporarily subsidized rental stock, depending on the length of the subsidy periods and the continued subsidization of new housing to ensure replacement of housing units and growth of the stock.

Regardless of the type of social/subsidized rental model, both countries have been coping with similar developments recently: decrease in funds for subsidized/social renting, a decline in the stock of affordable rental housing, as well as the increased focus of allocation to lowerincome households. In Germany, these results are due to the temporary system, term-limited subsidization that is not set up as a revolving fund. In the Netherlands, the focus of the government has been on moving towards a more market driven provision. Social/subsidized rental housing therefore is becoming a scarce service, particularly in large growing metropolitan areas where city governments are stepping up their efforts to build more.

Both countries are expected to increasingly house the needy in the private rental sector, where investments are largely driven by commercial motives. Germany has come further along this trajectory than the Netherlands, which more recently started betting on the market. The balance between regulation to protect the tenant and non-regulation to 'protect' commercial investors in rental housing turns out to be delicate, as the Dutch case illustrates in its enormous reduction of market share of private renting up to this century. German developments show that such 'tit for tat' influence quickly affected the supply side when tax breaks became less attractive for investors, higher returns were to be earned elsewhere (in non-subsidized residential real estate) and commercial investors were no longer investing in subsidized rental housing. 
This task was left to the housing companies whose stock is owned by local authorities. A system like the German one will work, as long as it can truly be flexible and build up quickly where needed.

A more 'permanent' stock of social dwellings provided and managed by social landlords within an institutional framework that makes the provision of affordable housing a public task as in the Dutch case, will allow for strong protection of the tenant. It also benefits the insiderexisting tenants-when the right to the rental contract is not means-tested, except at the entry point of dwelling allocation. Such lock-in prevents tenant mobility, also constraining tenants in need from accessing social renting.

Both the Dutch and German system allowed for some extent of freedom of operation. In the Dutch case, social landlords experiment with social entrepreneurship within the limits of the public task regulation, combining the commercial and social dimensions of residential real estate management with negotiation with the local authorities. The German supply-side system is based on negotiations taking place between investors and the subsidy providing local authority about the conditions under which subsidized housing will be realized. Cooperation is a must to realize affordable housing in urban areas.

\section{Acknowledgement}

An earlier version of this research was presented at an International Conference at the University of Calgary in 2018. I am grateful for Dr Tsenkova's invitation to participate in this exciting exhange of best practices for affordable housing and for her assistance in the development of this chapter.

\section{References}

Boelhouwer, P.; Van der Heijden, H. (1992) Housing systems in Europe. Delft: Delft University Press.

Brech, J. (2004) "Germany." In Gruis, V. and Nieboer, N. (eds). Asset Management in the Social Rented Sector. Policy and Practice in Europe and Australia. Dordrecht: Kluwer Academic Publishers, 141-160.

Bundesamt für Bauwesen und Raumordnung (2007) Wohnungs- und Immobilienmärkte in Deutschland 2006. Bonn: Bundesamt für Bauwesen und Raumordnung.

Bundesgesetzblatt (2013) Gesetz zur Errichtung eines Sondervermögens "Aufbauhilfe" und zur Änderung weiterer Gesetze (Aufbauhilfegesetz). Berlin: Bundestag, Part 1, No 38, 18 July.

Bundesinstitut für Bau-, Stadt- und Raumforschung (2012) Kommunale Strategien für die Versorgung einkommensschwächerer und sozial benachteiligter Haushalte. Bonn: Bundesamt für Bauwesen und Raumordnung.

Bundesministerium für Verkehr, Bau- und Wohnungswesen (2001) Der soziale Wohnungsbau wird reformiert. Bonn: Bundesministerium für Verkehr, Bau- und Wohnungswesen, No 49/1, 14 March.

Bundesregierung (2006) Wohngeld- und Mietenbericht 2006. Berlin: Bundesministerium für Verkehr, Bauund Wohnungswesen.

Bundesregierung (2009) Bericht über die Wohnungs- und Immobilienwirtschaft in Deutschland. Berlin: Bundesregierung, 3 June.

Busch-Geertsema, V. (2000) Housing Policy in Germany. Bremen: EUROHOME- IMPACT project working paper.

Busch-Geertsema, V. (2004) The Changing Role of the State in German Housing and Social Policy. European Journal of Housing Policy, 4(3): 303-321.

Cornelius, J.; Rzeznik, J. (2014) National Report for Germany. Bremen: Tenancy Law and Housing Policy in Multi-level Europe, Grant Agreement No. 290694.

Elsinga, M.; Haffner, M. (2020) "How the European Commission Affected Social Rental Housing in the Netherlands and Germany." In Anacker, K. B., Nguyen, M. T., and Varady, D. P. (eds). The Routledge Handbook of Housing Policy and Planning. New York: Routledge, 220-227. 
Elsinga, M.; Haffner, M.; Van der Heijden, H. (2005) A Unitary Rental Market in the Netherlands? Theoretical Exploration and Empirical Evidence. Paper presented at the ENHR-conference "Housing in Europe: New Challenges \& Innovations in Tomorrow's Cities”, Reykjavik, Iceland, 29 June-3 July.

Elsinga, M.; Haffner, M.; Van der Heijden, H. (2008) Threats to the Dutch Unitary Rental Market. European Journal of Housing Policy, 8(1): 21-37.

Elsinga, M.; Lind, H. (2013) The Effect of EU-Legislation on Rental Systems in Sweden and the Netherlands. Housing Studies, 28(7): 960-971.

European Commission (2009) Portfolio of Indicators for the Monitoring of the European Strategy for Social Protection and Social Inclusion - 2009 Update, September 2009 Update. Brussels: European Commission.

European Council (2000) Lisbon European Council. 23 and 24 March 2000. Presidency Conclusions. Lisbon: European Council. www.europarl.europa.eu/summits/lis1_en.htm. Accessed July 19, 2018.

Eurostat (n.d.-a) Statistics Explained: Category: Living Conditions Glossary. http://ec.europa.eu/eurostat/statistics-explained/index.php/Category:Living_conditions_glossary. Accessed June, 12, 2018.

Eurostat (n.d.-b) Statistics on Income and Living Conditions (EU-SILC) to Monitor Poverty and Social Exclusion in the European Union (EU). http://ec.europa.eu/eurostat/web/microdata/europeanunion-statistics-onincome-and-living-conditions. Accessed June, 12, 2018.

Eurostat (2017) Methodological Guidelines and Description of EU-SILC Target Variables, Directorate F: Social Statistics, Unit F-4: Quality of Life. August. http://ec.europa.eu/eurostat/documents/1012329/8658951/Household+data+-+housing.pdf/6c5216f2-b40b-49d6-a0aa-9c2c4bb32348. Accessed December 31, 2020.

Haffner, M. (2002) Dutch Social Rental Housing: the Vote for Housing Associations. Plenary paper presented at 9th European Real Estate Society Conference, Glasgow, UK, 4-9 June.

Haffner, M. E. A. (2011) Secure Occupancy in Rental Housing: A Comparative Analysis. Country Case Study: Germany. Delft: Delft University of Technology, http://repository.tudelft.nl/search/ir/?q=haffner andfaculty $=$ anddepartment $=$ andtype $=$ andyear $=$.

Haffner, M. (2018a) “The Role of Private Renting in France and the Netherlands.” In Schmid, C.U. (ed.) Tenancy Law and Housing Policy in Europe. Cheltenham: Edward Elgar Publishing, 19-38.

Haffner, M. E. A. (2018b) Housing Affordability in the European Union. IzR Informationen zur Raumentwicklung. No 4: pp. 22-33. www.bbsr.bund.de/BBSR/DE/Veroeffentlichungen/IzR/2018/4/Inhalt/inhalt.html?nn=422250. Accessed July 19, 2018.

Haffner, M.; Elsinga, M.; Hoekstra, J. (2008) Rent Regulation: The Balance between Private Landlords and Tenants in Six European Countries. European Journal of Housing Policy, 8(2): 217-233.

Haffner, M.; Hegedüs, J.; Knorr-Siedow, T. (2018) “The Private Rental Sector in Western Europe.” In József, H., Martin, L., and Vera, H. (eds), Private Rental Housing in Transition Counties. An Alternative to Owner Occupation? London: Macmillan Publishers Ltd., 3-40.

Haffner, M.; Hoekstra, J.; Oxley, M.; Van der Heijden, H. (2009) Bridging the Gap between Market and Social Rented Housing in Six European Countries. Amsterdam: IOS Press BV. http://repository.tudelft.nl/view/ir/uuid: d35c0ed4-7874-4413-8b90-25352ec8c980/. Accessed July 19, 2018.

Haffner, M.; Van der Veen, M.; Bounjouh, H. (2014) National Report for the Netherlands. Delft: Delft University of Technology, Tenancy Law and Housing Policy in Multi-level Europe, Grant Agreement No. 290694.

Hochstenbach, C.; Ronald, R. (2020). The Unlikely Revival of Private Renting in Amsterdam: ReRegulating a Regulated Housing Market. Environment and Planning A: Economy and Space, 52(8): 16221642.

Hoekstra, J.; Haffner M.; Van der Heijden H.; Oxley M. (2012) "Private Rental Landlords in Europe." In Smith, S. J., Elsinga, M., Fox O’Mahony, L., Seow Eng, O., Wachter, S., and Tsenkova, S. (eds). International Encyclopedia of Housing and Home, Vol. 5. Oxford: Elsevier, 387-392.

Kholodilin, K. A. (2017) Quantifying a Century of State Intervention in Rental Housing Germany. Urban Research \& Practice, 10(3): 267-328.

Kofner, S. (2014) The Private Rental Sector in Germany, OECD Research on Private Rental Sector. Consultancy Report: Germany. No place of publication: Stefan Kofner.

Kofner, S. (2017) Social Housing Germany: An Inevitably Shrinking Sector? Critical Housing Analysis, 4(1): 61-71. 
Kromhout, S.; Wittkämper, L. (2019) Stand van de woonruimteverdeling. Wachttijden en verdeling in de tijd. Amsterdam: RIGO Research en Advies.

Leutner, B. (1990) Wohnungspolitik nach dem 2. Weltkrieg. Bonn-Bad Godesberg: Bundesministerium für Raumordnung, Bauwesen und Städtebau.

Ministerie van Binnenlandse Zaken en Koninkrijksrelaties (2016) Cijfers over Wonen en Bouwen 2016. The Hague: Ministerie van Binnenlandse Zaken en Koninkrijksrelaties.

Oxley, M.; Lishman, R.; Brown, T.; Haffner, M.; Hoekstra, J. (2010) Promoting Investment in Private Rented Housing Supply. International Policy Comparison. London: Department for Communities and Local Government, Crown Copyright, Queen's Printer and Controller of Her Majesty's Stationery Office. https://assets.publishing.service.gov.uk/government/uploads/system/uploads/attachment_data/file/6359/1759530.pdf. Accessed July 19, 2018.

Oxley, M.; Tang, C.; Lizieri, C.; Mansley, N.; Makic, D.; Haffner, M.; Hoekstra, J. (2015) Prospects for Institutional Investment in Social Housing. London: IPF.

Priemus H.; Haffner, M. (2017) How to Redesign a Rent Rebate System? Experience in the Netherlands, Housing Studies, 32(2): 121-139.

Van der Heijden, H. M. H.; Haffner, M. E. A.; Reitsma. A. A. (2002) Ontwikkeling van de woonuitgaven in zes Westeuropese landen. Delft: Delft University Press.

Van der Schaar, J. (1986) De non-profit huursektor: woningbeheer en-exploitatie. Delft: Delft University Press. Van der Schaar, J. (1987) Groei en bloei van het Nederlandse volkshuisvestingsbeleid. Delft: Delft University Press.

Whitehead, C.; Scanlon, K.; Monk, S.; Tang, C.; with Haffner, M.; Lunde, J.; Lund Andersen, M.; Voigtländer, M. (2016). Understanding the Role of Private Renting - A Four-Country Case Study. Cambridge \& Copenhagen: University of Cambridge \& Boligokonomisk Videncenter. 